San Jose State University

SJSU ScholarWorks

Faculty Publications, Meteorology and Climate Science

Meteorology and Climate Science

April 2002

\title{
An Examination of Anomalously Low Column Ozone in the Southern Hemisphere Midlatitudes During 1997
}

\author{
Eugene C. Cordero \\ San Jose State University, eugene.cordero@sjsu.edu \\ Terrence R. Nathan \\ University of California - Davis
}

Follow this and additional works at: https://scholarworks.sjsu.edu/meteorology_pub

Part of the Atmospheric Sciences Commons, Climate Commons, and the Meteorology Commons

\section{Recommended Citation}

Eugene C. Cordero and Terrence R. Nathan. "An Examination of Anomalously Low Column Ozone in the Southern Hemisphere Midlatitudes During 1997" Geophysical Research Letters (2002): 27-1-27-4. https://doi.org/10.1029/2001GL013948

This Article is brought to you for free and open access by the Meteorology and Climate Science at SJSU ScholarWorks. It has been accepted for inclusion in Faculty Publications, Meteorology and Climate Science by an authorized administrator of SJSU ScholarWorks. For more information, please contact scholarworks@sjsu.edu. 


\title{
An examination of anomalously low column ozone in the Southern Hemisphere midlatitudes during 1997
}

\author{
Eugene C. Cordero \\ Monash University, Clayton Vic., Australia
}

Terrence R. Nathan

Atmospheric Science Program, University of California, Davis, CA, USA

Received 20 August 2001; revised 12 December 2001; accepted 12 December 2001; published 11 April 2002.

[1] Observations from both ground-based and satellite instruments show record low column ozone abundance between $20^{\circ} \mathrm{S}$ and $40^{\circ} \mathrm{S}$ during 1997 . The 1997 monthly averaged column ozone from the Total Ozone Mapping Spectrometer (TOMS) is up to 25 Dobson units (DU) lower than the TOMS climatological mean (1979-1996) and up to 20 DU below the previous record low values. Observations from the Halogen Occultation Experiment show that below average ozone concentrations during 1997 were confined primarily to the lower stratosphere. Residual circulation statistics calculated from the United Kingdom Meteorological Office temperature analyses indicate that circulation anomalies during 1997 can account for $\sim 5-10$ DU/month decrease in column ozone between $20^{\circ} \mathrm{S}$ and $50^{\circ} \mathrm{S}$. At these latitudes during 1997, structural characteristics of the ozone and residual circulation fields both suggest a connection with the equatorial quasi-biennial oscillation. INDEX TERMS: 0341 Atmospheric Composition and Structure: Middle atmosphere - constituent transport and chemistry (3334); 0340 Atmospheric Composition and Structure: Middle atmosphere - composition and chemistry

\section{Introduction}

[2] During the past two decades the distribution of various stratospheric trace gases has been closely monitored in order to understand and quantify the relative importance of anthropogenic versus natural processes in affecting the spatial and temporal evolution of the ozone layer [WMO, 1999]. Here we examine the role of one of the most striking natural processes in the atmosphere - the quasi-biennial oscillation (QBO) - in producing the anomalously low ozone values observed during 1997 in the Southern Hemisphere (SH).

[3] During 1997, anomalously low column ozone abundance was reported over various locations in the $\mathrm{SH}$, including record low events over Lauder, New Zealand $\left(45^{\circ} \mathrm{S}, 170^{\circ} \mathrm{E}\right)$ in August [Brinksma et al., 1998]. Connor et al.'s [1999] analysis shows that below average ozone levels occurred throughout the $\mathrm{SH}$ during 1997, particularly during the winter and spring seasons. The mechanisms responsible for these strikingly low ozone values remain unclear. The findings described below, however, suggest that the QBO may have played an important role in these anomalously low ozone values.

\section{Ozone Observations}

[4] Two independent, complementary data sets are used to construct the ozone distributions in the $\mathrm{SH}$ for individual and multiyear periods. One data set is from the Total Ozone Mapping
Spectrometer (TOMS), which provides information on the total column ozone (TCO) distribution. The other data set is from the Upper Atmosphere Research Satellite (UARS) Halogen Occultation Experiment (HALOE), which provides information on ozone concentration at specific levels between $100 \mathrm{hPa}(\sim 16 \mathrm{~km})$ and $0.01 \mathrm{hPa}(\sim 80 \mathrm{~km})$. The HALOE data can be vertically integrated between these levels to yield information on the column ozone abundance. The HALOE column ozone and TOMS TCO can then be compared for structural consistency.

[5] Figure 1 shows the monthly mean-column ozone abundance averaged between $20^{\circ} \mathrm{S}$ and $40^{\circ} \mathrm{S}$ based on data from TOMS and HALOE. Consider first the TOMS data. TOMS shows the middle latitude TCO during 1997 to be $\sim 10-25$ DU below the long-term mean, values that are significantly lower than any year on record. During July and August the TCO was more than 10 DU below the previously recorded lowest values of 1998 and 1999. Inspection of daily TOMS fields between $20^{\circ} \mathrm{S}$ and $40^{\circ} \mathrm{S}$ indicates that the low monthly means were primarily due to consistently low daily TCO, not from brief, extreme low TCO events. The largest negative TCO anomalies during 1997 are between $20^{\circ} \mathrm{S}$ and $40^{\circ} \mathrm{S}$; poleward of $40^{\circ} \mathrm{S}$ the negative TCO anomalies monotonically approach zero by $60^{\circ} \mathrm{S}$.

[6] Figure 1 also shows the UARS HALOE column ozone abundance between $100 \mathrm{hPa}$ and $1 \mathrm{hPa}$ and between $20^{\circ} \mathrm{S}$ and $40^{\circ} \mathrm{S}$ averaged for the period 1992-1999; 1997 also was separately compiled for comparison with the 1992-1999 HALOE climatology. We have used Randel's et al. [1998] monthly climatology of HALOE Version 18 data. Due to the satellite-observing pattern, observations for February, November, and December between $20^{\circ} \mathrm{S}$ and $40^{\circ} \mathrm{S}$ are missing. The HALOE column ozone abundance was calculated by summing the vertical ozone profiles between $100 \mathrm{hPa}$ and $1 \mathrm{hPa}$. Because HALOE does not measure ozone concentrations in the troposphere, i.e., below $100 \mathrm{hPa}$, the tropospheric component of column ozone is not accounted for, which results in the HALOE calculated column ozone being $\sim 40-50 \mathrm{DU}$ below the TOMS measurements. However, the spatial structures of the HALOE calculated column ozone and the TOMS TCO are in good agreement. Moreover, like the TOMS data, the HALOE data shows 1997 column ozone abundance to be significantly $(\sim 10-25$ DU) below the HALOE climatological average. The generally good agreement between the HALOE and TOMS column ozone (spatial) fields provides confidence for using the HALOE profiles to identify where the low ozone concentrations exist in relation to the entire ozone column.

[7] A comparison of HALOE ozone profiles between 1992 and 1999 indicates that below $30 \mathrm{~km}$, where the ratio of dynamical to photochemical time scales is very small [Nathan and Li, 1991], the 1997 ozone concentrations were generally below the climatological concentrations. For example, 1997 HALOE ozone concentrations in the lower stratosphere averaged between $20^{\circ} \mathrm{S}$ and $40^{\circ} \mathrm{S}$ from June though August were nearly 20\% lower than the climatological concentrations. Similar results also were observed throughout the winter and spring months between $20^{\circ} \mathrm{S}$ and $50^{\circ} \mathrm{S}$. Because the 


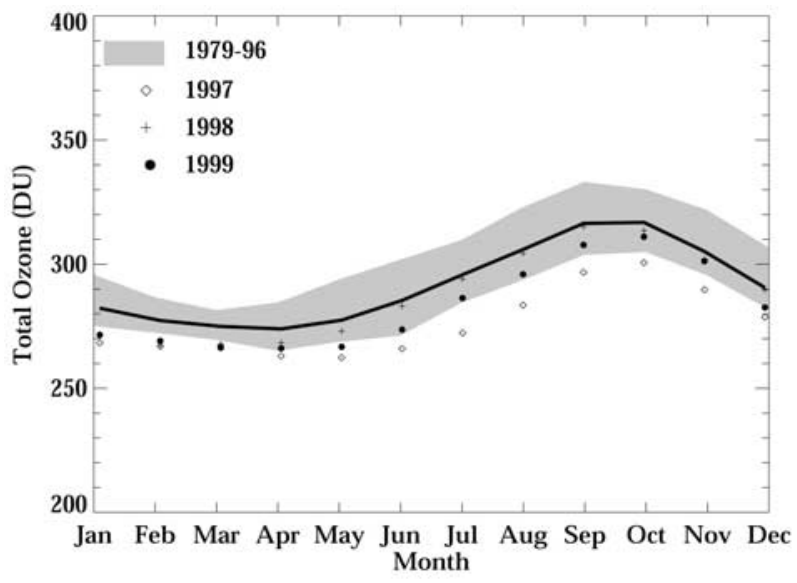

Figure 1. Time series of monthly-averaged column ozone averaged between $20^{\circ} \mathrm{S}$ and $40^{\circ} \mathrm{S}$ based on two independent data sets: total column ozone data from TOMS and column ozone calculated from HALOE ozone profiles. The thick line represents the time-mean TOMS observations spanning the period 19791996; the dotted line represents the time-mean HALOE calculated ozone column spanning the period 1992-1999. The diamonds, plus signs, and solid circles represent TOMS measurements during 1997, 1998 and 1999, respectively; the squares represent the HALOE calculated column ozone for 1997.

midlatitude ozone anomalies are most pronounced in the dynamically controlled lower stratosphere, we focus attention on the dynamical mechanism(s) that contributed to the 1997 low ozone anomalies by comparing 1997 and climatological residual circulation statistics.

\section{Residual Circulation}

[8] The residual circulation is a useful diagnostic for understanding large-scale meridional transport in the stratosphere and thus is used here to investigate ozone variability in the lower stratosphere during 1997. Following Rosenlof [1995], the Transformed Eulerian Mean (TEM) residual circulation $\left(v^{*}, w^{*}\right)$ is calculated using the thermodynamic energy and mass continuity equations, where $v^{*}$ and $w^{*}$ represent, respectively, the TEM meridional and vertical wind components. Following Rosenfield et al. [1997], a climatology of monthly-mean residual circulation fields was constructed using 1992-1999 diabatic heating rates calculated from United Kingdom Meteorological Office (UKMO) temperature analyses.

[9] The structure of the residual circulation, which is affected in large part by planetary wave variability [Li et al., 1995; Nathan et al., 2000], generally shows weak upward motion in the Tropics and strong downward motion in the winter hemisphere midlatitudes. Although the 1997 and climatological residual circulations have similar large-scale structures, there are some important differences, which, as explained below, contribute to the 1997 column ozone anomalies.

[10] Figure 2 shows the June-July climatological average of the zonal-mean ozone tendency $\left[\chi_{i}\right.$; solid lines $]$ that is due solely to the advection by the residual circulation $\left[\left(v^{*}, w^{*}\right)\right.$; arrows $]$. The $\chi_{t}$ field was obtained by computing the zonal-mean ozone advection, $-v^{*} \chi_{y}-w^{*} \chi_{z}$, where the $\left(\chi_{y}, \chi_{z}\right)$ fields were obtained from the HALOE climatology. The negative ozone tendencies in the Tropics generally result from the upward transport of ozone poor air to higher altitudes, whereas in the SH middle-to-high latitudes, positive ozone tendencies result from the downward transport of ozone rich air to lower altitudes.

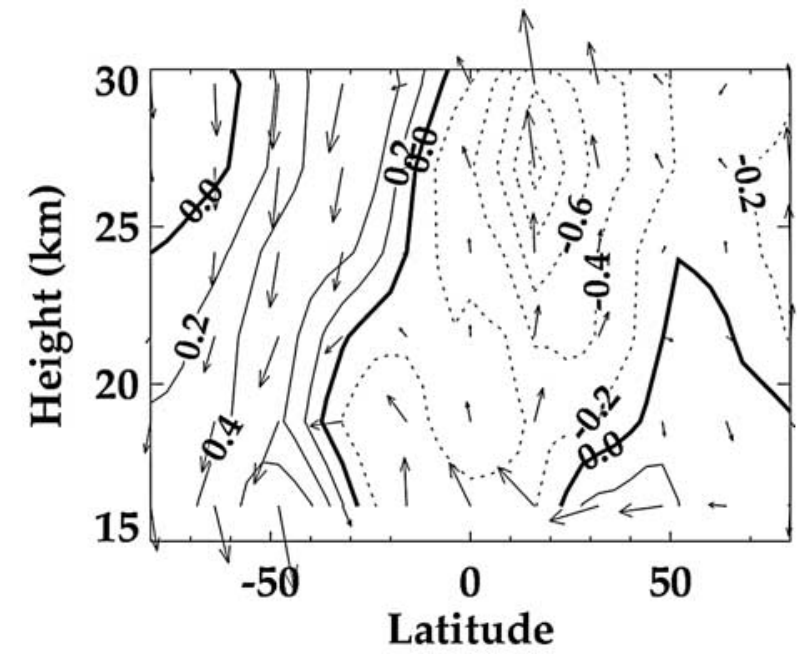

Figure 2. The distribution of the June-July averaged zonalmean ozone tendency that is due solely to the residual circulation. The contour interval is $0.02 \mathrm{ppmv} / \mathrm{month}$, where dashed contours denote negative tendencies and the thick line denotes the zero contour. Vectors denote the components of the residual circulation.

[11] To better understand the role of dynamical variability and transport in affecting the 1997 ozone anomaly distribution, we construct a $\chi_{t}$ anomaly field that is due to advection by the 1997 residual circulation. Because there are uncertainties associated with calculating ozone gradients from the limited 1997 HALOE data, we calculated the 1997 values of $\chi_{t}$ using the HALOE climatological distribution of ozone, a procedure that produces smoother fields without altering our conclusions. The 1997 distribution of $\chi_{t}$ was then subtracted from the climatological $\chi_{t}$ field, resulting in a zonal mean, ozone tendency anomaly field. The corresponding column ozone anomaly field was then obtained by vertically integrating $\chi_{t}$ between $15 \mathrm{~km}$ and $30 \mathrm{~km}$.

[12] Figure 3 shows the column ozone anomaly field that results from the difference between the 1997 and climatological residual circulations. Negative ozone tendencies are evident during April

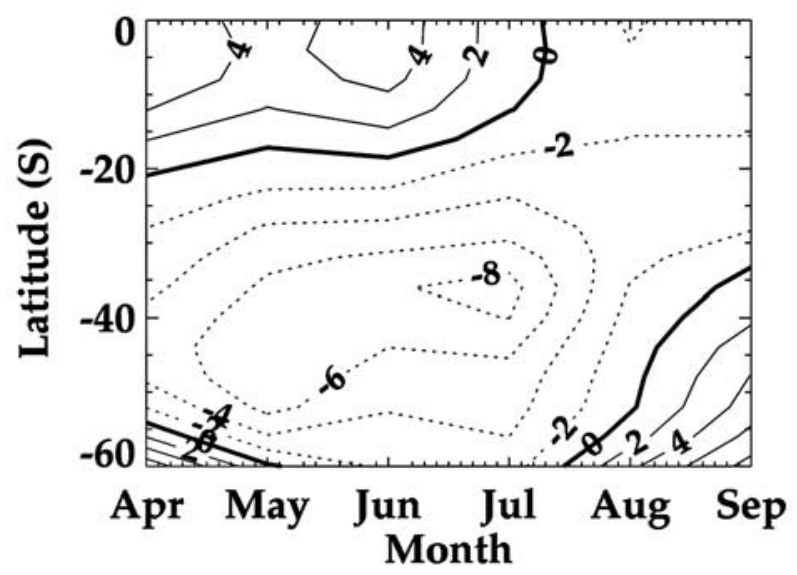

Figure 3. Total ozone tendencies due to 1997 residual circulation anomalies. The tendencies were calculated by subtracting the 1997 residual circulation anomalies from the climatological (19921998) anomalies. The ozone tendencies (DU/month) are based on a vertical integration between 15 and $30 \mathrm{~km}$. The contour interval is $2 \mathrm{DU} / \mathrm{month}$, where dashed contours denote negative tendencies, and the thick line denotes the zero contour. 


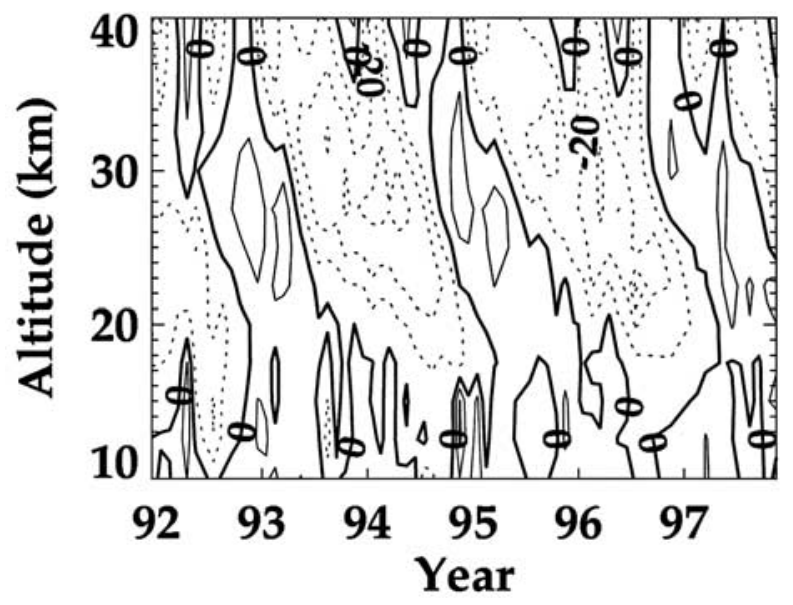

Figure 4. Zonally averaged zonal winds at the equator from the HRDI. The contour interval is $5 \mathrm{~m} / \mathrm{s}$ and the thick line denotes the zero wind line.

through August between $20^{\circ} \mathrm{S}$ and $55^{\circ} \mathrm{S}$, with a maximum of -8.3 $\mathrm{DU} /$ month near $35^{\circ} \mathrm{S}$ during late June. These negative tendencies, which account for about half of the observed anomaly, are primarily due to a weaker residual circulation in the subtropics and middle latitudes during 1997 compared with other years. The following section examines the connection between the tropical QBO and the 1997 ozone anomaly distribution.

\section{The QBO During 1997}

[13] The QBO is an important source of tracer variability in both the Tropics and midlatitudes [e.g. O'Sullivan and Dunkerton, 1997; Cordero and Nathan, 2000]. The relationship between the QBO and tropical tracers is relatively well understood. The relationship between the QBO and midlatitude tracers, however, is less well understood, though evidence suggests that the seasonal cycle plays an important role in this relationship. Briefly, the seasonal cycle modulates the QBO, which in turn affects the extratropical wave fluxes [Kinnersley and Tung, 1998] and the residual circulation [Tung and Yang, 1994], both of which combine to affect tracer gradients. There also is evidence suggesting that the extratropical QBO signal is an enhancement of the subtropical QBO signal, which may extend into the middle latitudes by the horizontal advection of zonal momentum into the winter hemisphere [Jones et al., 1998; Kinnersley, 1999].

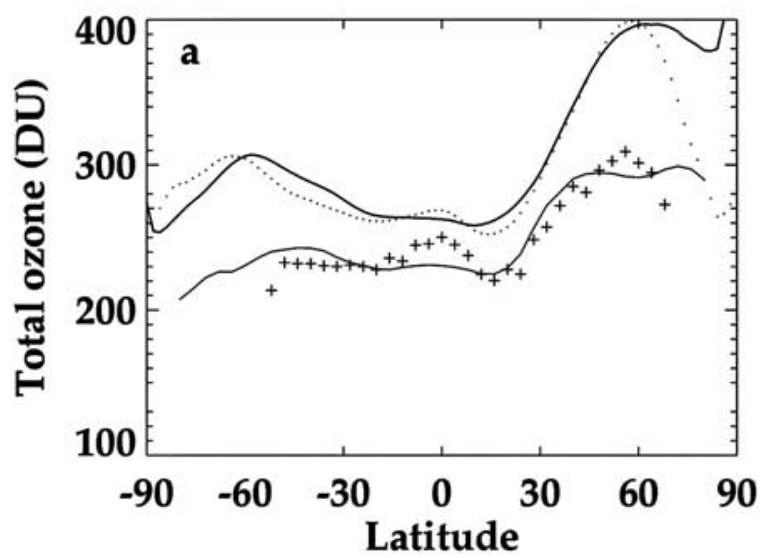

[14] Figure 4 shows a time series of zonally averaged zonal winds at the equator constructed from the UARS High Resolution Doppler Imager (HRDI). During early 1997, the descending westerly phase of the QBO is apparent near $25 \mathrm{~km}$ altitude. As explained by Plumb and Bell [1982] and shown schematically in their Figure 1, as the westerlies descend, the associated downward motion brings higher ozone concentrations to lower altitudes thus producing positive ozone anomalies in the lower tropical stratosphere. In the subtropics there is upward motion that brings lower ozone concentrations to higher altitudes thus producing negative ozone anomalies there.

[15] The meridional structure of 1997 column ozone variations for the March and June/July time periods is shown in Figure 5 using both TOMS and HALOE observations. Because the column ozone is concentrated in the lower stratosphere, it is intimately connected to the QBO and its variations. During March in the Tropics, there are large positive ozone anomalies equatorward of $20^{\circ} \mathrm{S}$ and $10^{\circ} \mathrm{N}$ in both the TOMS and HALOE data. The positive ozone anomalies in the Tropics are accompanied by negative anomalies in both the Northern Hemisphere (NH) subtropics and Southern Hemisphere (SH) midlatitudes. By June/July, the positive ozone anomalies in the Tropics are accompanied by large negative ozone anomalies between $15^{\circ} \mathrm{S}$ and $60^{\circ} \mathrm{S}$, whereas in the $\mathrm{NH}$, negative ozone anomalies remain in the subtropics. Thus the structure and timing of the extratropical ozone anomalies suggest a strong link with the tropical QBO.

[16] For example, from late 1994 to early 1995, large positive ozone anomalies (not shown) associated with strong QBO westerly wind shears (WWS) were observed in the Tropics. Although the magnitude of the 1994/1995 tropical ozone anomalies is similar to 1997 values, the 1994/1995 midlatitude response is very weak. The primary difference between the 1994/1995 and 1997 time periods is the timing of the maximum QBO wind shears. During 1994/ 1995, the WWS are maximized between September and November, while during 1997, the WWS are maximized between February and April. During 1995, the WWS occurred too early to produce a large midlatitude response in the SH, while in 1997, the QBO and returning wintertime circulation were timed to produce a large midlatitude response.

\section{Conclusions}

[17] During 1997 column ozone abundance in the Southern Hemisphere midlatitudes was lower than previously recorded. The lowest monthly averaged column ozone values occurred between $20^{\circ} \mathrm{S}$ and $50^{\circ} \mathrm{S}$ during May through September. Observations from HALOE indicate that most of the anomalously low ozone values

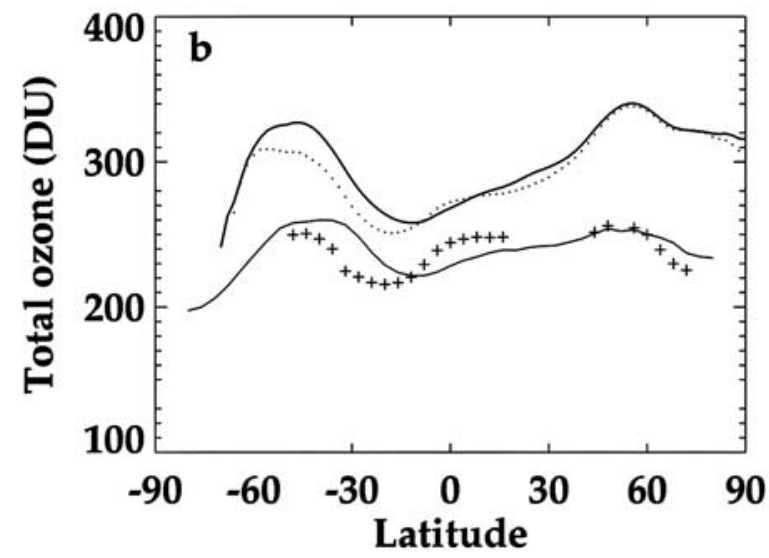

Figure 5. HALOE and TOMS zonally averaged total ozone distributions for (a) March and (b) June/July. The thick solid line represents the TOMS climatology and the thin solid line represents the HALOE climatology. The dot and plus symbols represent observations collected in 1997 from TOMS and HALOE, respectively. 
occurred in the lower stratosphere, a region controlled by dynamical rather than chemical processes.

[18] A comparison of 1997 and climatological (1992-1999) residual circulation statistics indicates that the zonal-mean meridional circulation accounts for a significant portion of the observed 1997 ozone anomalies. In particular, during 1997 the magnitude of the zonal-mean meridional transport accounts for a 25-10 DU/month decrease in column ozone between $20^{\circ} \mathrm{S}$ and $50^{\circ} \mathrm{S}$.

[19] The meridional transport and column ozone variations during 1997 are mutually consistent and indicative of a QBO connection. For example, during winter 1997, positive (negative) ozone anomalies are observed between $0^{\circ}$ and $20^{\circ} \mathrm{S}\left(20^{\circ} \mathrm{S}\right.$ and $60^{\circ} \mathrm{S}$ ), which is consistent with modeling studies of QBO-induced circulation anomalies [Jones et al., 1998; Kinnersley, 1999]. Although planetary wave variability may have contributed to the 1997 ozone anomalies, we note that the 1997 planetary wave amplitudes calculated from NCEP analyses do not appear to be anomalous. Thus the extratropical extension of the QBO, particularly the timing of the westerly phase, appears to play the primary role in producing the 1997 ozone anomalies.

[20] Based on analysis of TOMS and HALOE ozone data sets and the analysis of residual circulation statistics, we conclude that anomalously low ozone events in the midlatitudes will be favored when the westerly phase of the QBO occurs early in the calendar year, as it did in 1997.

[21] Acknowledgments. We thank the TOMS processing team and J. M. Russell III, the principal investigator for the HALOE instrument. In addition, we are grateful to W. J. Randel for producing the HALOE climatology, J. E. Rosenfield for calculating the heating rates, and Professor David Karoly and Dr. Shuhua Li for their helpful comments.

\section{References}

Brinksma, E. J., et al., Analysis of record-low ozone values during the 1997 winter over Lauder, New Zealand, Geophys. Res. Lett., 15, 2785-2788, 1998.

Connor, B. J., G. E. Bodeker, R. L. McKenzie, and I. S. Boyd, The total ozone anomaly at Lauder, NZ in 1997, Geophys. Res. Lett., 26, 189-192, 1999.

Cordero, E. C., and T. R. Nathan, The influence of wave- and zonal-mean ozone feedbacks on the quasi-biennial oscillation, J. Atmos. Sci., 57, 3426-3442, 2000.

Jones, D. B. A., H. R. Schneider, and M. B. McElroy, Effects of the quasibiennial oscillation on the zonally averaged transport of tracers, J. Geophys. Res., 103, 11235-11249, 1998.

Kinnersley, J. S., Seasonal asymmetry of the low- and middle-latitude QBO circulation anomaly, J. Atmos. Sci., 56, 1140-1153, 1999.

Kinnersley, J. S., and K. K. Tung, Modeling the global interannual variability of ozone due to the equatorial QBO and to extratropical planetary wave variability, J. Atmos. Sci., 55, 1417-1428, 1998.

Li, L., T. R. Nathan, and D. J. Wuebbles, Topographically forced planetary wave breaking in the stratosphere, Geophys. Res. Lett., 22, 2953-2956, 1995.

Nathan, T. R., and L. Li, Linear stability of free planetary waves in the presence of radiative-photochemical feedbacks, J. Atmos. Sci., 48, $1837-$ $1855,1991$.

Nathan, T. R., E. C. Cordero, L. Li, and D. J. Wuebbles, Effects of planetary wave breaking on the seasonal variation of total column ozone, Geophys. Res. Lett., 27, 1907-1910, 2000.

O'Sullivan, D., and T. J. Dunkerton, The influence of the quasi-biennial oscillation on global constituent distributions, J. Geophys. Res., 102, $21,731-21,743,1997$

Plumb, A. R., and R. C. Bell, A model of the quasi-biennial oscillation on an equatorial beta-plane, Quart. J. Roy. Meteor. Soc., 108, 335-352, 1982.

Randel, W. J., F. Wu, J. M. Russell III, A. Roche, and J. W. Waters, Seasonal cycles and QBO variations in Stratospheric $\mathrm{CH}_{4}$ and $\mathrm{H}_{2} \mathrm{O}$ observed in UARS HALOE data, J. Atmos. Sci., 55, 163-185, 1998.

Rosenfield, J. E., D. B. Considine, P. E. Meade, J. T. Bacmeister, C. H. Jackman, and M. R. Schoeberl, Stratospheric effects of Mount Pinatubo aerosols studied with a coupled two-dimensional model, J. Geophys. Res., 102, 3649-3670, 1997.

Rosenlof, K. H., Seasonal cycle of the residual mean meridional circulation in the stratosphere, J. Geophys. Res., 100, 5173-5191, 1995.

Tung, K. K., and H. Yang, Global QBO in circulation and ozone. Part II: A simple mechanistic model, J. Atmos. Sci, 51, 2708-2721, 1994.

World Meteorological Organization (WMO), Scientific assessment of ozone depletion: 1998, WMO Global Ozone Research and Monitoring Project, Report No. 44, WMO, Geneva, 1999.

E. C. Cordero, Centre for Dynamical Meteorology and Oceanography, Monash University, Clayton Vic 3168, Australia. (Eugene_cordero@) yahoo.com)

T. R. Nathan, Atmospheric Science Program, Department of Land, Air and Water Resources, One Shields Ave., University of California, Davis, CA 95616, USA. (trnathan@ucdavis.edu) 